\title{
Domesticating Light and Shadows in the Neolithic: The Dombate Passage Grave (A Coruña, Spain)
}

\section{A. César González-García, Benito Vilas-Estévez, Elías López-Romero \& Patricia Mañana-Borrazás}

\begin{abstract}
Research on the Neolithic monuments and dwellings of Atlantic Europe has shown that plays of light and colour were tools for the social and symbolic construction of the world. The integration of the architectures into the surrounding landscape and the incorporation of the surrounding landscape into the architectures were an essential part of this logic. In this context, recent research in the megalithic passage grave of Dombate has evidenced an unusual physical manifestation of sunlight, which interacts with the decorated back stone. The light-and-shadow phenomenon occurs at sunrise during the period of winter solstice. In this paper we discuss the particulars of this phenomenon and we argue that sunlight when it penetrates the passage and chamber at sunrise on these dates may have dictated how the art was located and applied to the structural stone. Such differentiation seems to have had important cultural and ritual significance and encoded/embedded meaning for the tomb builders and may have implications for the consideration of the symbolic dimension of similar architectures in Atlantic Europe.
\end{abstract}

\section{Introduction}

Dombate (Cabana de Bergantiños, A Coruña, northwest Spain: Fig. 1) is one of the best-known Neolithic monuments in the Iberian Peninsula. Not only is it one of the most paradigmatic examples of Iberian passage graves, but it is also one that epitomizes the main structural, socio-economic, territorial and symbolic dimensions of the Neolithic and Early Bronze Age megalithic phenomenon across the European Atlantic façade.

Its relevance in historic terms as being one of the best-studied megalithic monuments in Galicia has been highlighted by the presence of an elaborate decorative programme that includes carvings and most notably a complex set of paintings (Carrera Ramírez \& Bello Diéguez 1997). An interesting aspect of this decoration is how natural light might be used to perceive and highlight particular parts of the decoration. This has been investigated in the past for other kinds of art, most significantly for the Palaeolithic (see e.g.
Pettitt et al. 2017). Indeed, the use and manipulation of natural light by directing a beam of light to illuminate a particular space inside a built structure may appear both in timber structures as well as in stone buildings. In the present paper we focus on a particular type of building, a megalithic passage grave.

Megalithic monuments are found in several different parts of the world, most notably in Europe and the Mediterranean. These structures have varying chronologies and typologies (see Thomas 2012 for a recent general review). It has been suggested that light-and-shadow effects could have been incorporated in the earliest examples of megalithic monuments, such as Göbekli Tepe, Turkey (dated to 9000 вс: Schmidt 2006; see e.g. Belmonte \& González-García 2016; Magli 2016, for recent reviews; see also Bosch 2018, for a possible beam of light acting as a sun clock in Çatalhöyük). Interestingly, these are among the first also to bear a broad decorative programme, mostly with bas-relief images of animals and anthropomorphic figures. Such effects were also allegedly incorporated 


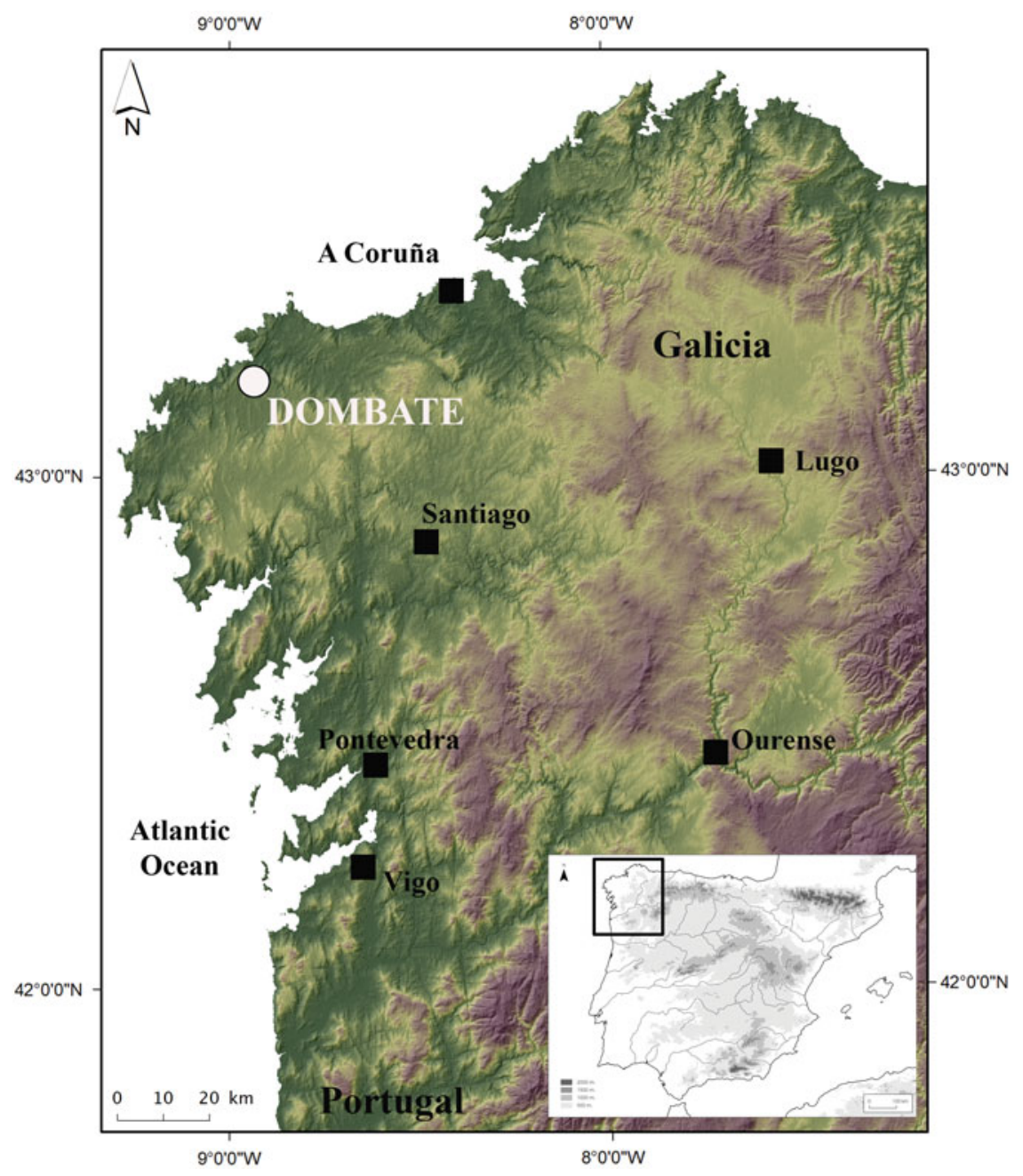

Figure 1. Dombate is located in the northwest of Galicia (Spain).

into Neolithic European structures (see Bradley 1989 for a general treatment), especially in those connected with the dead, such as dolmens and passage graves. Notable examples are Newgrange in Ireland (Patrick 1974; Prendergast 2014, 1273; Ray 1989; see also Hensey 2017), Maeshowe in the Orkney Islands (MacKie 1997), Bryn Celli Ddu in Anglesey (Burl 1983, 29-30; Burrow 2010) or Fontvielle in southern France (Saletta 2011).

In the present paper we aim at investigating how light and shadow might have influenced the decorative programme in Dombate by a separation of the motives possibly dictated by how the light enters at particular moments of the year. Specifically, the orientation of the passage grave towards winter solstice sunrise means that only for a number of days before and after this moment does direct sunlight penetrate and illuminate the back stone. Arguably this might have been perceived as a significant moment that needed to be further emphasized by the inclusion of the decorative programme.

We investigate these illumination events by direct measurements in the megalithic structure and by a $3 \mathrm{D}$ reconstruction of the whole site, included in a digital terrain model that allows for a realistic reconstruction of the events at the moment of use of the chamber. Section 2 gives the archaeological details of the site; section 3 presents the state of the art regarding archaeoastronomical research on illumination events and megalithic art. Section 4 introduces the methodology employed. Section 5 presents our results and section 6 the discussion. Finally, we present a summary of our work in the conclusion of section 7 .

\section{Dombate and its archaeological context}

The adoption of the Neolithic way of life in the northwest of the Iberian peninsula has traditionally been 
considered to be relatively recent when compared to other Iberian regions (for a recent review, see Prieto Martínez et al. 2012). The data from areas such as the Morrazo Peninsula (Pontevedra) may nonetheless indicate the existence of an initial Neolithic regional horizon-with the presence of impressed pottery-that precedes the development of the monumental architectures in the area. Sites such as A Cunchosa (Cangas, Pontevedra: Suárez Otero 1997), O Regueiriño (Moaña, Pontevedra: Prieto Martínez 2010) or Monte dos Remedios (Moaña, Pontevedra, with a pit dated to $5780 \pm 40 \mathrm{BP}, 4722$ 4534 cal. ВC, ${ }^{1}$ Ua-32670: Bonilla Rodríguez et al. 2006) seem to correspond to an early moment of the neolithization process.

Galician and northern Portugal megalithic monuments have been the object of scientific study since the last third of the nineteenth century and major advances were made in the characterization of the phenomenon during the 1980s and 1990s. Mounds are found throughout the region, with a preference for locations in elevated land. Location in low topographic areas is less common (but see e.g. López-Romero et al. 2015, 355-7).

Regarding chronological issues, however, accurate analysis of the moments of construction, use and abandonment of the monuments is largely biased in the region by the poor preservation of organic materials suitable for radiocarbon dating (e.g. bone). Most available radiocarbon dates for the Neolithic and the megalithic phenomenon thus come from charcoal remains or from sediments found in different archaeological contexts. Owing to the exceptional preservation of painted decoration in some of the monuments and to advances in AMS radiocarbon dating, a very significant milestone was achieved in the late 1990s and early 2000s with the direct dating of the decorated orthostats in monuments such as Coto dos Mouros (Rodeiro, Pontevedra, CAMS-83631: $5540 \pm 70$ вр, 4523-4259 cal. вс) or Pedra Cuberta (Vimianzo, A Coruña, CAMS-77923: 5010 \pm 60 вр, 3953-3666 cal. BC). These dates confirmed the hypothesis that the paintings were part of the symbolic programme of the monuments from the moment of their construction and that they were not a much later addition (Steelman et al. 2005).

Considering all this, the oldest dates available for tumular contexts in Galicia and northern Portugal place the emergence of the phenomenon in the second half of the fifth millennium BC. This is the case for instance of Forno dos Mouros 5 (Ortigueira, A Coruña, UA-20009: 5635 \pm 50 вр, 4580-4353 cal. BC), Coto dos Mouros (Rodeiro, Pontevedra, CAMS-83631: 5540 \pm 70 вр, 4523-4259 cal. BC) or Areita (Paredes da Beira, Vila Real, GrA-18518: 5170 \pm 60 BP, 4226-3797 cal. вс: Alonso Mathías \& Bello Diéguez 1997). From these initial moments it seems that different types of architectures were built and coexisted; the architectural solutions for the funerary space were thus varied, with orthostatic and non-orthostatic chambers, with pits or with the presence of wooden implements. During the first half of the fourth millennium this architectural diversity continues, with polygonal chambers without passage (e.g. Cha de Parada, Porto; Portela do Pau, Viana do Castelo; Carapito 1, Guarda; all in northern Portugal), mounds without inner orthostatic structures (e.g. Ponte da Pedra, A Coruña; Cha de Santinhos 2, Porto: see e.g. Jorge 1987), large earthen mounds (e.g. Madorra da Granxa, Lugo), small tumuli (e.g. Monte de Dorna, A Coruña) and passage graves. It is during the second half of the fourth millennium that passage graves became probably the most common megalithic architecture in the region; among them, the passage grave of Dombate stands out from the rest for its characteristics and biography.

First described by M. Murguía (1865), Dombate soon drew the attention of local historians and archaeologists. It eventually became internationally known during the 1930s, when some of the most renowned European archaeologists of the age (Breuil 1933; Leisner 1938) discussed different aspects of its architecture and symbolism, contributing to the scientific renewal that was slowly taking place in Galicia and in the north of Portugal (López-Romero 2013, 83).

The first scientific excavations were undertaken in the late 1980s (Bello Diéguez 1992/1993). It was then discovered that to an original small megalithic chamber $($ c. $2.4 \times 1.9 \mathrm{~m})$ covered by a relatively small mound, a second, larger, seven-stone chamber $(3.4 \times 2 \mathrm{~m})$ provided with a passage was added nearby during the first half of the fourth millennium cal. BC (Alonso Mathías \& Bello Diéguez 1997). A large mound (c. $24 \mathrm{~m}$ in diameter) was built and partially covered with a crust of medium-sized stones (coraza). According to Bello Diéguez (1992/1993) and Lestón Gómez (2011), the whole mound would be probably covered by this coraza; however, it is often the case in the region that this arrangement was more prominent in the area surrounding the entrance (Fig. 2; see e.g. the case of the excavated mound in Forno dos Mouros in Toques, A Coruña: Aboal \& Porto 2012). The later mound in Dombate covered not only the recent monument, but also the earlier one, making it invisible. Later research has confirmed that this phenomenon of integration was 


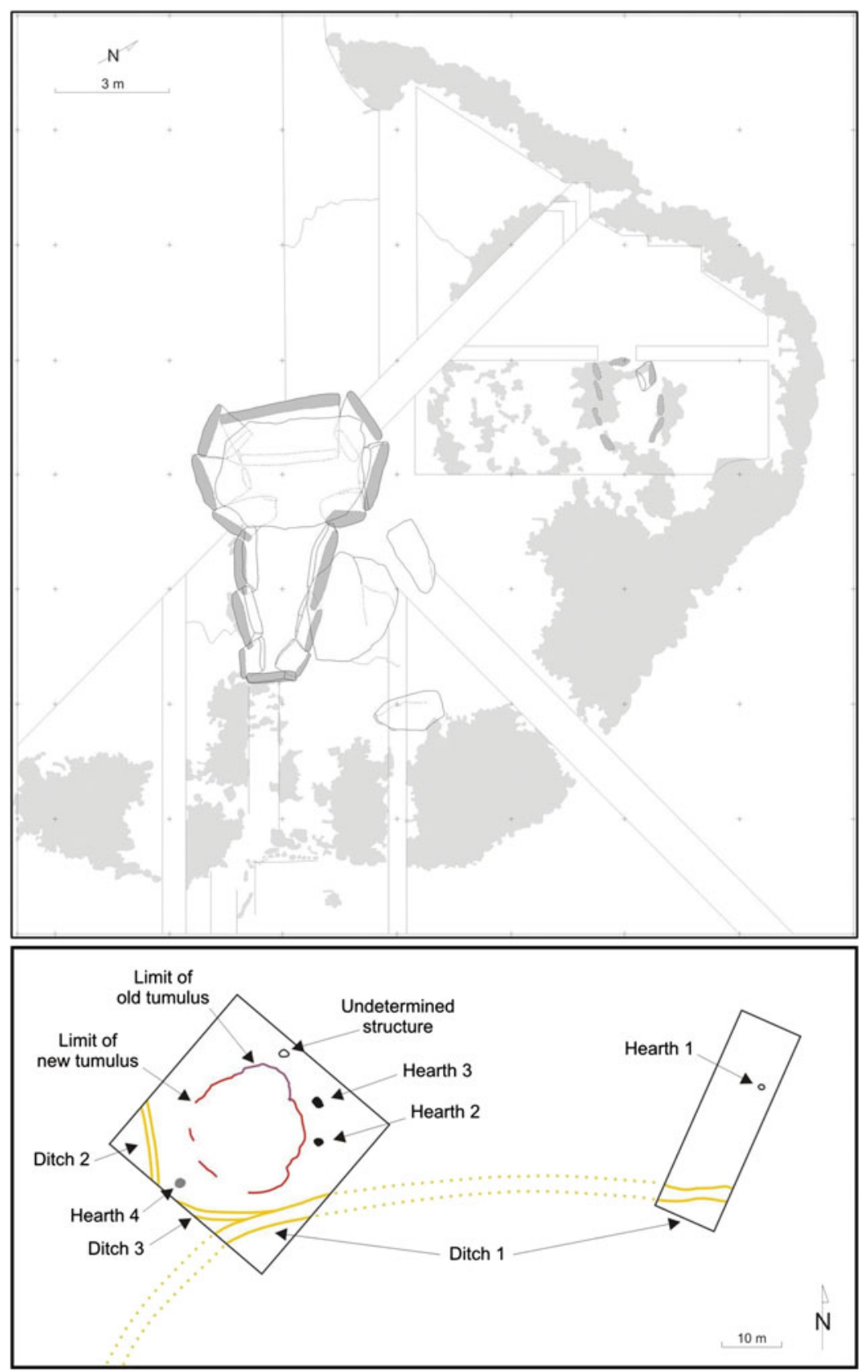

Figure 2. Plan of the dolmen of Dombate. The megalithic structures of the old and new chambers can be appreciated. (Bottom) general plan of the structures found during the last interventions with special attention to the ditches and hearths. (Modified by Anxo Rodríguez Paz after Bello Diéguez 1992/1993, 141, fig. 1.)

a quite recurrent trend of the funerary monumentbuilding tradition in this (e.g. Mañana-Borrazás 2005) and other European regions, one that also concerned other forms of megalithic monuments-i.e. standing stones and stelæ-and that was repeated over time, as indicated by the many punctuated stages of construction, reuse and re-signification (Bradley \& Williams 1998).
All orthostats in the chamber and corridor of the passage grave are decorated with paintings-black and red linear motifs and dots on a white background-and engravings (these appear only in the chamber). These decorations seem to be contemporary to the date of construction of the monument (first half of the fourth millennium BC), as the preparation layers for the paintings and some ${ }^{14} \mathrm{C}$ contexts 


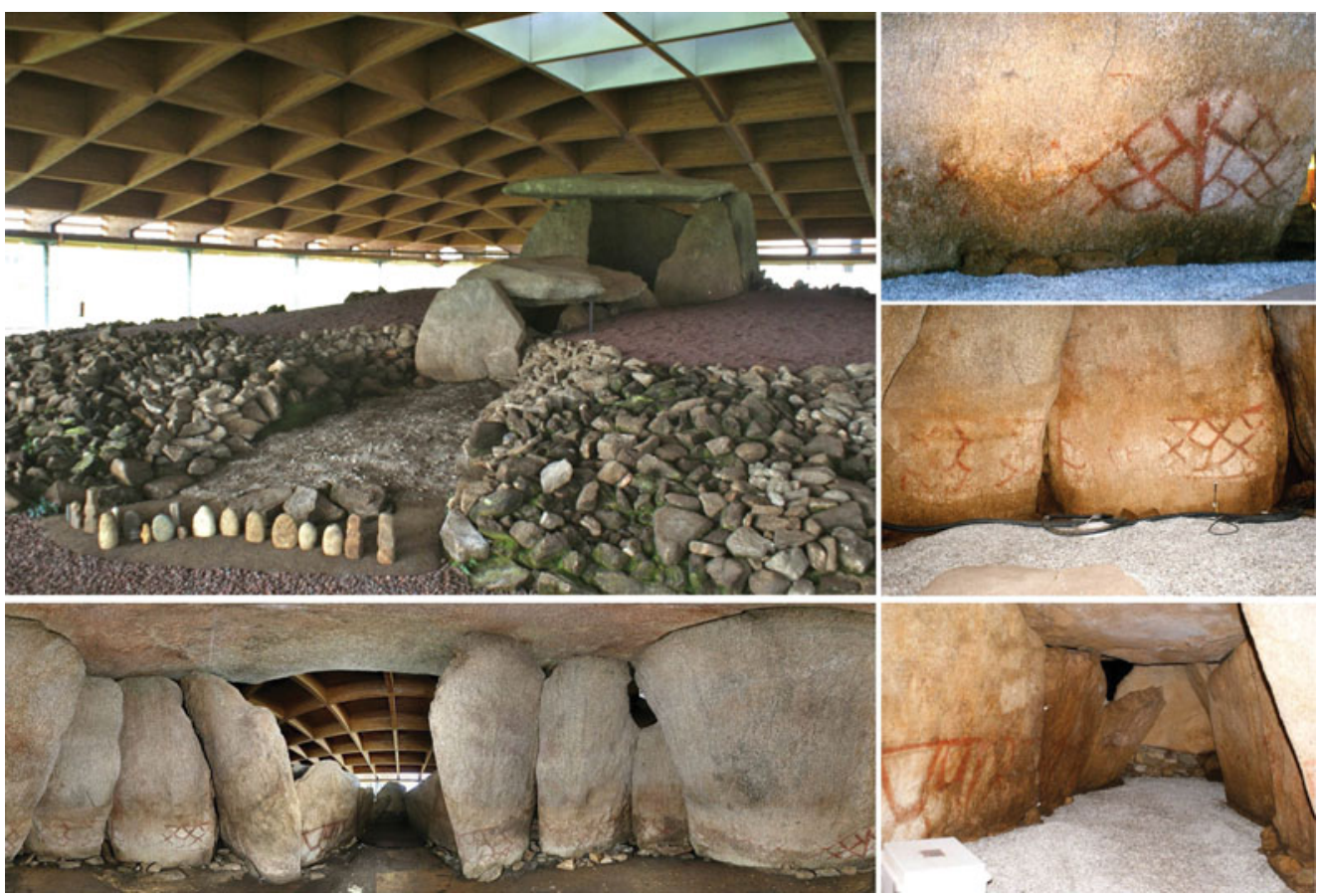

Figure 3. The dolmen of Dombate. (Top, left) The mound surrounds the megalithic structure. The stone cover is more prominent close to the entrance. A number of idols were found set on their sockets at the opening of the passage. A closing stone blocks the entrance to the corridor. (Bottom and right) The interior of the megalithic structure presents a very elaborate art programme, including paintings and carvings.

suggest (Carrera Ramírez 2011, 243). There is evidence that the stone surface was regularized with a white mortar made of kaolin and water with the probable addition of an organic adhesive. The motifs painted over this preparation layer are dominantly red lines-organized in geometric patternsdelimited by alternating red and black dotted lines. The paintings seem to be organized into two levels, vertically separated by a horizontal red band. The upper register has almost completely disappeared from the chamber. In the corridor, the painting of this upper level consists of zigzags made in black. The lower level is better preserved throughout the monument, and the motifs depicted there seem much more complex. Big red bands delimit irregular spaces, which are smaller and more varied in the chamber (Fig. 3, bottom and right).

One of the most interesting results of the 1980s excavations was the identification of a series of 'idols' placed in sockets especially made to locate them standing up at the entrance of the dromos, an open-air passage way leading into the megalithic corridor, indicating the special nature of this area within the whole monument. A total of 20 'idols' were identified, 17 of them standing in situ and forming a line in front of a series of flat slabs that were placed in the manner of a threshold (see Fig. 3, top). All of them have a more or less anthropomorphic shape, in some cases emphasized by means of incision or carving (i.e. abstract representation of the head and shoulders). They are not exclusive to Dombate; similar items are known in the Neolithic of northwest Iberia, having mostly been found in other megalithic passage graves (e.g. Cova da Moura in Noia; Mina da Parxubeira in Mazaricos: see Fábregas Valcárce 1993). Further excavations in the corridor enabled the discovery of a vertical stone $c .1 \mathrm{~m}$ in height blocking its access (see Fig. 3, top). This stone, still in situ at the time of the excavation, was the main element evidencing the closure of the corridor after the primary use of the passage grave. The setting of this element was dated 3011-2586 cal. BC (CSIC-892: $4230 \pm 70$ вр: Alonso Mathías \& Bello Diéguez 1995) as a terminus post quem thanks to the presence of a small hearth underlying a series of stones placed immediately behind the vertical stone.

Recent excavations have completed our view of the monument's history and meaning. A most striking result of this recent work has been the identification of a number of hearths and ditches around the monument (Lestón Gómez 2011; Fig. 2). Three 
hearths were found in close proximity to it. They seem to be related to the monument, as they are set in the layer that corresponds to the occupation floor contemporary to it (Lestón Gómez 2011, 202-5). A fourth hearth was found c. $90 \mathrm{~m}$ to the east of the monument, most probably related to a settlement area (see description of ditch 1 below) that was in use after the access to the monument had been closed (Lestón Gómez 2011, 221).

A total of three ditches were identified. While ditch 2 and ditch 3 might be contemporary to the Neolithic occupations of Dombate, ditch 1 (c. $1 \mathrm{~km}$ of estimated perimeter) seems to be later in date. The northeastern limit of this ditch is located just 4 $\mathrm{m}$ southeast of the monument, and probably delimits a Bronze Age settlement area. The exact nature of the link between the monument and the area enclosed by the ditch remains unknown, but it inevitably recalls the debate about the correlation between the domestic and the symbolic spheres in past societies (Criado Boado et al. 2000). Increasing evidence of such linear features beneath or around monuments is being found elsewhere in Galicia (e.g. Chousa Nova: Domínguez-Bella \& Bóveda Fernández 2011; As Gándaras: Méndez Fernández 2007), drawing our attention to the structural, chronological, cultural and symbolic complexity of the sites.

\section{Illumination event and paintings}

A different but necessarily complementary level of analysis concerns the setting of Dombate and its relationship to the multiple dimensions of the landscape, including the sky (García Quintela \& González García 2009; Knapp \& Ashmore 1999). The relation of the megalithic monuments with the sky is one of the most debated problems in archaeoastronomy (see e.g. González-García \& Belmonte 2010). For several decades archaeoastronomy has tried to devise a methodology to discover if the orientation of megaliths was related to the heavenly bodies. Despite numerous efforts, it was not until the last decades of the past century that a number of works showed that if taken together, several groups of possibly related megaliths in relatively close areas appeared to present patterns of orientation that arguably were related to the sun or the moon when close to the horizon (Hoskin 2001; Ruggles 1999).

Those results proved intentionality in the orientations, but they did not tackle the cumbersome problem of the intent behind such orientations. Recent developments focus on a more cultural context in what has been termed cultural astronomy (Iwaniszewski 1989). A complementary approach recently advocated is that of skyscape archaeology (Silva \& Henty 2015). However, in general most of these results ignored the relationship of the monuments with their surrounding landscape.

Landscape archaeology has no a priori reason to stop its gaze at the horizon line, especially considering that the sky presents a number of wellunderstood regularities (Ruggles \& Saunders 1993). This is an advantage, because those regularities allow the researcher to replicate with a high degree of confidence how it was at any moment in the past. According to Sprajc (2018), 'the sky can be considered an integral part of any archeological landscape', and as such may have specific meaning (Ashmore 2008) and provides hints to understand the landscape organization (Knapp \& Ashmore 1999). The built landscape, including megaliths, and the meaningful landscape are thus mutually related (García Quintela \& González García 2009; Knapp \& Ashmore 1999). However, we do not have clear references as to the cultural and social understanding, connection and character that the sky had for the peoples who built the megaliths, if it had any at all. In short, we lack their social meaning of the sky. The interaction of the material remains with the landscape, and in particular the sky, may provide a hint towards that social meaning (Criado Boado 2012).

\section{Illumination events inside passage grave tombs}

Although megalithic chambers often show clear asymmetries in shape, working or material of the stones used in the corridor or the megalithic chamber (see e.g. Laporte et al. 2002), to a first degree of generalization, we may consider that passage graves have an axis of symmetry that was typically defined by their entrance (see Silva 2014 for this issue in greater depth). In many cases, these were not randomly oriented (Hoskin 2001; Ruggles 1999), and in several instances the simplest explanation for the coherence of the orientation could be the rising or setting of heavenly bodies. Depending on the orientation and shape of the megalithic structure, natural light could penetrate the dark inner areas, creating different illumination effects. It is important to consider that entrances are wide but restrictive, and so there is a window of illumination, i.e. particular areas at the interior of the megalith could have been illuminated on several days while other parts remain in shadows and darkness. The illuminated part can be highlighted, and can be made special by the use of light inside the monument (see e.g. González-García 2018 for a recent review). 
Those illumination effects were incorporated and have been studied in several Neolithic European structures (see Bradley 1989 for a general treatment and McCluskey 2015 for a recent review), especially in those connected with the dead, dolmens and passage graves, such as Newgrange in Ireland (Patrick 1974; Prendergast 2014, 1273; Ray 1989), Maes Howe in the Orkney Islands (Burl 1983, 30; Hedges 1984, 160), Bryn Celli Ddu in Anglesey (Burl 1983, 29-30; Burrow 2010) or Fontvielle in southern France (Saletta 2011).

The vast majority of the megalithic chambers in the Iberian Peninsula open towards the eastern sector of the horizon (González-García \& Belmonte 2010; Hoskin 2001). Therefore, most cases of direct illumination of the chamber or corridor occur at sunrise. The tholos of Huerta Montero (Almendralejo, Spain) presents an interesting case. The tholos chamber is slightly sunken in the terrain, and this leads to the first sunlight of winter solstice directly hitting the back part of the chamber before it is projected towards the entrance as the sun rises in the sky (González-García 2018).

Lozano and colleagues (2014) studied the possible illumination effects at the summer solstice sunrise (SSSR here after) in Menga (Antequera, Málaga, Spain). Given the width of the entrance, by using the concept of the 'window of visibility' (Silva 2014), even though the megalith is oriented topographically towards the conspicuous hill of 'Peña de los Enamorados' and its orientation is directed towards an area further north than the northernmost rising of the sun during summer solstice (SSSR), at this particular time of the year the sunlight would enter and illuminate a large part of the north side of the chamber. The authors claim that this event may have been relevant for the builders, as the north and south sides of the chamber have important structural differences. However, this idea seems to work better if the illumination is from the full moon close to winter solstice rather than the SSSR, as in this case the full moon does completely illuminate all orthostats on the north side of the chamber (González-García 2018). Lozano et al. (2014) argue that there are other large monuments in the south of Spain with similar illumination effects, such as the dolmen of Alberite (see also Belmonte \& Hoskin 2002, 85-90). The internal structures there, such as the vertical slabs inside the corridor and chamber, prevent light from entering particular areas where burials were found, except at the time of SSSR. A similar situation occurs at the dolmen of Soto, where the inner vertical slabs prevent light from entering the innermost areas except at the equinox (Lozano et al. 2014).

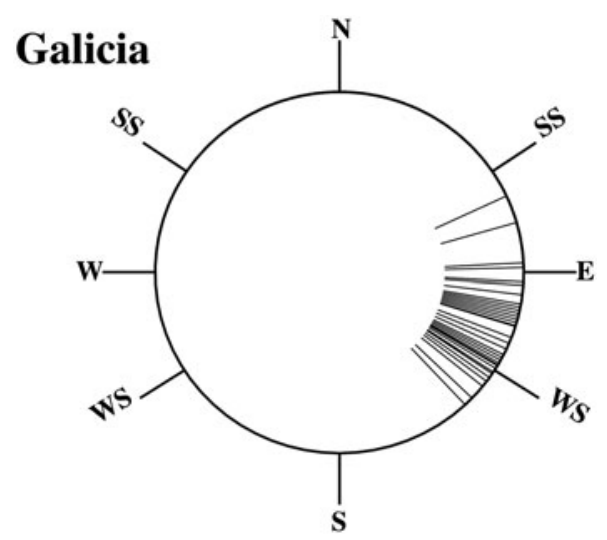

Figure 4. Orientation diagram for 62 passage graves in Galicia. Short lines indicate the orientation of each dolmen. The outside strokes indicate the cardinal directions and the positions of sunrise and sunset for winter solstice (WS) and summer solstice (SS).

The case of Dombate

In this respect, the discussion of the astronomical significance of Dombate has been limited, until now, to the analysis of the orientation of its chamber and passage towards winter solstice sunrise (WSSR here after) for the epoch (Hoskin 2001, 235; see Table 1), but little research has been conducted to comprehend the possible implications of this orientation, one of the most common in Galicia (Fig. 4; GonzálezGarcía et al. 2017).

Table 1 presents the orientation data for both the old and new monuments of Dombate. These measurements were obtained with two professional tandems (Suunto 360), including a compass plus a clinometer. The data provide the mean of several measurements of the orientation of the axis of symmetry for the corridor and chamber of the two monuments. This axis was defined by finding the centre of the corridor and the chamber back stone and marking these points with a surveyor's rod. The nominal precision of the compass is $1 / 4^{\circ}$ while that of the

Table 1. Data for the orientation of the main axis of the two monuments of Dombate (old and new; Hoskin 2001 data are provided in the last row for reference; latitude $43^{\circ} 11^{\prime} 28.5^{\prime \prime} \mathrm{N}$; longitude $8^{\circ} 58^{\prime} 4.23^{\prime \prime} W ; 198$ m.a.s.l.). The columns identify the the azimuth (A), the altitude of the horizon in that particular direction $(h)$ and the astronomical declination $(\delta)$. For details, see text.

\begin{tabular}{|l|l|l|l|}
\hline Monument & $\mathbf{A}\left(^{\circ}\right)$ & $\mathbf{h}\left(^{\circ}\right)$ & $\boldsymbol{\delta}\left({ }^{\circ}\right)$ \\
\hline Dombate old & 111 & $2^{1 / 2}$ & -13.6 \\
\hline Dombate new & $1261 / 2$ & 3 & -23.6 \\
\hline & 127 & 3 & -24 \\
\hline
\end{tabular}




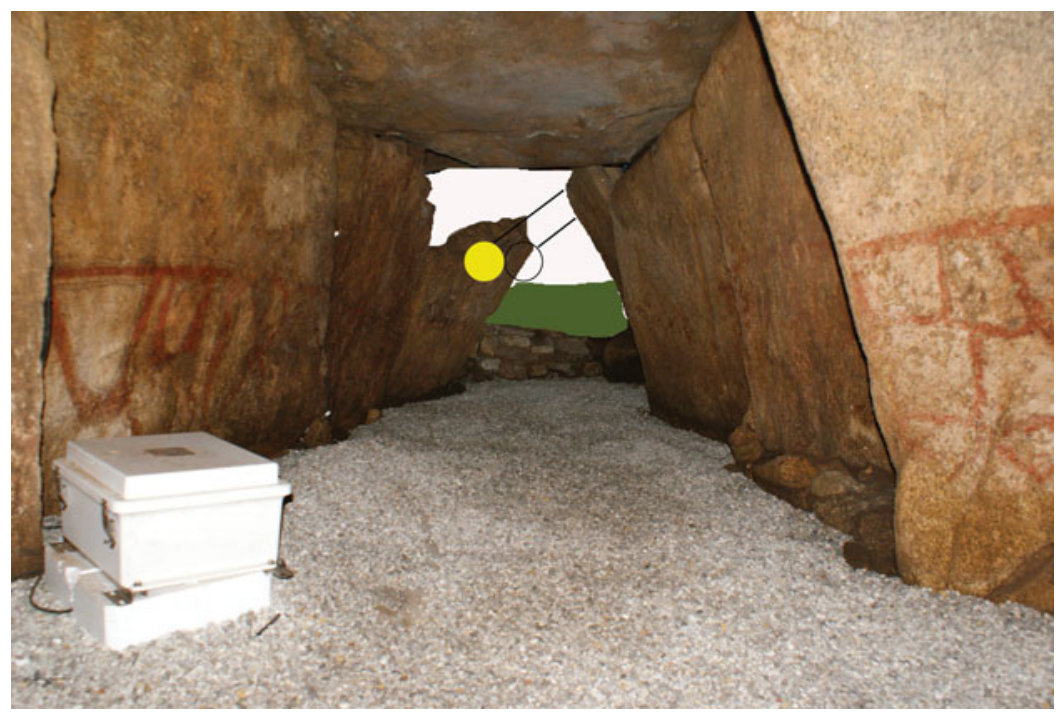

Figure 5. Horizon reconstruction indicating the sun's path as seen today (full circle) and in 3000 BC (empty circle).

clinometer is $1 / 2^{\circ}$. However, given the procedure of determination of the measured line, a conservative possible error of $10 \mathrm{~cm}$ should be estimated in placing the centres in a line of $c .10 \mathrm{~m}$. This means that a conservative estimate of the error in a single measurement for the azimuth would be closer to $1 / 2^{\circ}$. The standard deviation of all measurements is below this level. The magnetic readings were checked for the possibility of local magnetic alterations by taking readings from different sides of the line defined above, finding no significant deviations that may indicate local magnetic alterations. Also, the readings were corrected by comparing with astronomical observations at the moment of sunrise. The measurements presented in Table 1 are our own for both the old and new monuments and we present those by Hoskin $(2001,235)$ for the new monument for comparison. Finally, the last column provides the astronomical declination, where atmospheric refraction has been considered (Schaeffer 1993), which is the appropriate quantity to compare local directions in a given landscape (as provided by the azimuth and the altitude of the horizon) with global ones such as the rising or setting of heavenly bodies. In this respect the error in our measurements translates into an uncertainty of $34^{\circ}$ in declination. For the epoch of construction of both monuments of Dombate the southernmost rise of the sun at WSSR happened at a declination of $c .-24^{\circ}$.

It should be stressed that the data in Table 1 are for the symmetry axis, while the width of the window of visibility as defined by Silva (2014) is of $431^{1} 2^{\circ}$, (from $1191^{1} 2^{\circ}$ to $163^{\circ}$ ) and the symmetry axis is slightly off this window of visibility. When located at the back stone along this symmetry axis, the one we have used to define the orientation of the passage grave, the window defined by the entrance is $73 / 4^{\circ}$.

One implication of this orientation and the physical configuration of the chamber and corridor is that, despite facing the area where the rise of several heavenly bodies would happen, only during a small number of days centred on WSSR would the inner parts of the chamber and its paintings be lit up by direct sunlight (Fig. 5).

Because the entrance to the corridor has a width as seen from the back stone of $734^{\circ}$, illumination would occur for one month before and after WSSR.

The illumination event is now precluded by the location of the closing stone mentioned above at the entrance of the corridor. Figure 6 indicates the illuminated parts today due to the small breaks at the corners of that stone. It is worth noting that inspection on site of the illumination on 21 December 2014 indicated that the illuminated part never reaches further up than the painted red geometrical pattern of the back stone.

In order to mimic the effects of the illumination without removing the closing stone and replicate the illumination at the time of use of the chamber, we have built a 3D model of the mound and megalithic structure and incorporated it into a Digital Terrain Model (DTM) of the surrounding area in order to provide the landscape context. The Digital Terrain Model was obtained from the Spanish Geographic Institute (Instituto Geográfico Nacional). ${ }^{2}$ The model was built by interpolation from LIDAR flights of the Spanish Plan of Aerial Orto-Photography (PNOA). The model has a passband of $5 \mathrm{~m}$ and 


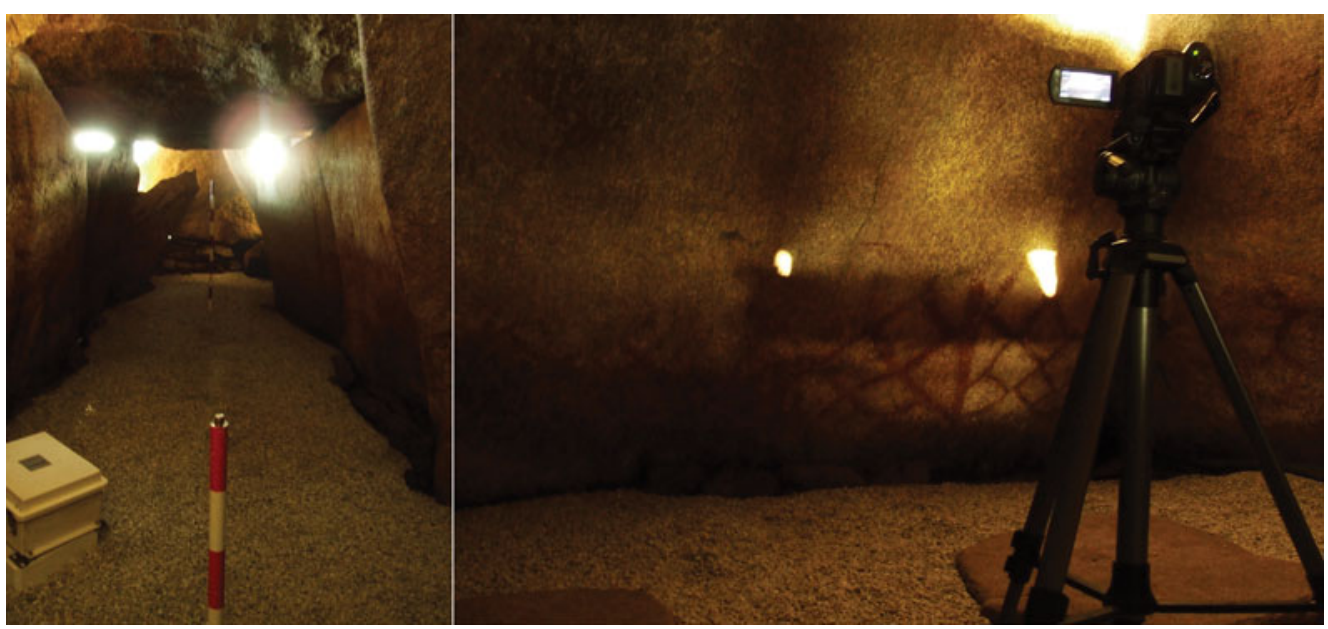

Figure 6. Illumination of the paintings as seen on 20 December 2013. (Left) View of the corridor from the chamber. The small openings above the closing stone allow small beams to illuminate the back stone (right).

employs the ETRS89 geodetic reference system and UTM projection. A horizon was produced incorporating this model to the Horizon software, kindly provided by A.K. Smith. The horizon thus has a resolution of $7 \frac{1}{2}$ arcmin for the distance of the horizon of interest for the simulation: this is nearly a quarter of the solar disc. The model was oriented according to the measurements taken by the authors and presented above, and incorporated into the DTM by taking six GPS measurements around the monument.

The 3D model of the megalithic structure was built using Blender from an archaeological plan of the monument (Bello Diéguez 1992/1993) and by comparing it with the laser-scan of the passage grave (Cebrián del Moral \& Yáñez Rodríguez 2011). We did not use directly the laser-scan-based model as this was a really heavy model to be incorporated within the astronomical software. Thus our model has a simplified structure with fewer points and is easier to handle. The mean deviation of our model compared to the laser scan is $2.5 \mathrm{~cm}$, which translates into an angular deviation of less than $10 \mathrm{arcmin}$.

These features were duly treated into the Stellarium software ${ }^{3}$ employing the Scenery 3D feature (Zotti 2016) that allows setting the correct time, permitting us to observe the process of illumination of the back stone paintings during WSSR (see Video in the Supplementary Material). Figure 7 gives a virtual reconstruction of how the illumination would proceed on WSSR for different times as the sun rises and climbs up in the sky a few minutes after sunrise at the time of use of the tomb. It can be observed that, after a first flash of light projecting the entrance frame into the red and white paintings of the back stone, such a trapezoidal frame shifts downwards to the right of the stone as the sun gains altitude above the horizon, until the back stone returns to shadows after a while (nearly 45 minutes). It is again interesting to note that the illuminated part never reaches further up than the red horizontal band, as first hinted at by the on-site observation.

\section{Discussion}

Few processes have provoked so many changes in human societies as the introduction of production economy strategies (e.g. Vicent García 1991; Zvelebil 1990). This introduction (or its genesis, depending on the regions) provided unprecedented perspectives not only for the economic sphere, but also for the social and ideological spheres (e.g. Renfrew 1994; Shennan 2013). The nature and specificities of such changes are still today the object of a continuous debate in Iberia and beyond (e.g. Bayliss et al. 2007; Bentley et al. 2003; Gkiasta et al. 2003; Robb 2013; Zilhão 2000), contributing to make the studies on these societies one of the most challenging fields within the archaeological discipline. In western Europe, Neolithic societies were the first to leave a visible artificial-architectural-mark in the landscape that can be defined as durable (e.g. Sherratt 1990, 164). This becomes especially evident from around $4700 \mathrm{BC}$, when the cultural landscapes of western Europe are dramatically transformed by the construction of conspicuous funerary mounds and stelæ that evidence the existence of a new notion of space (e.g. Criado Boado 2015).

When we talk about an orientation, we are considering a specific direction, a measurement in that 

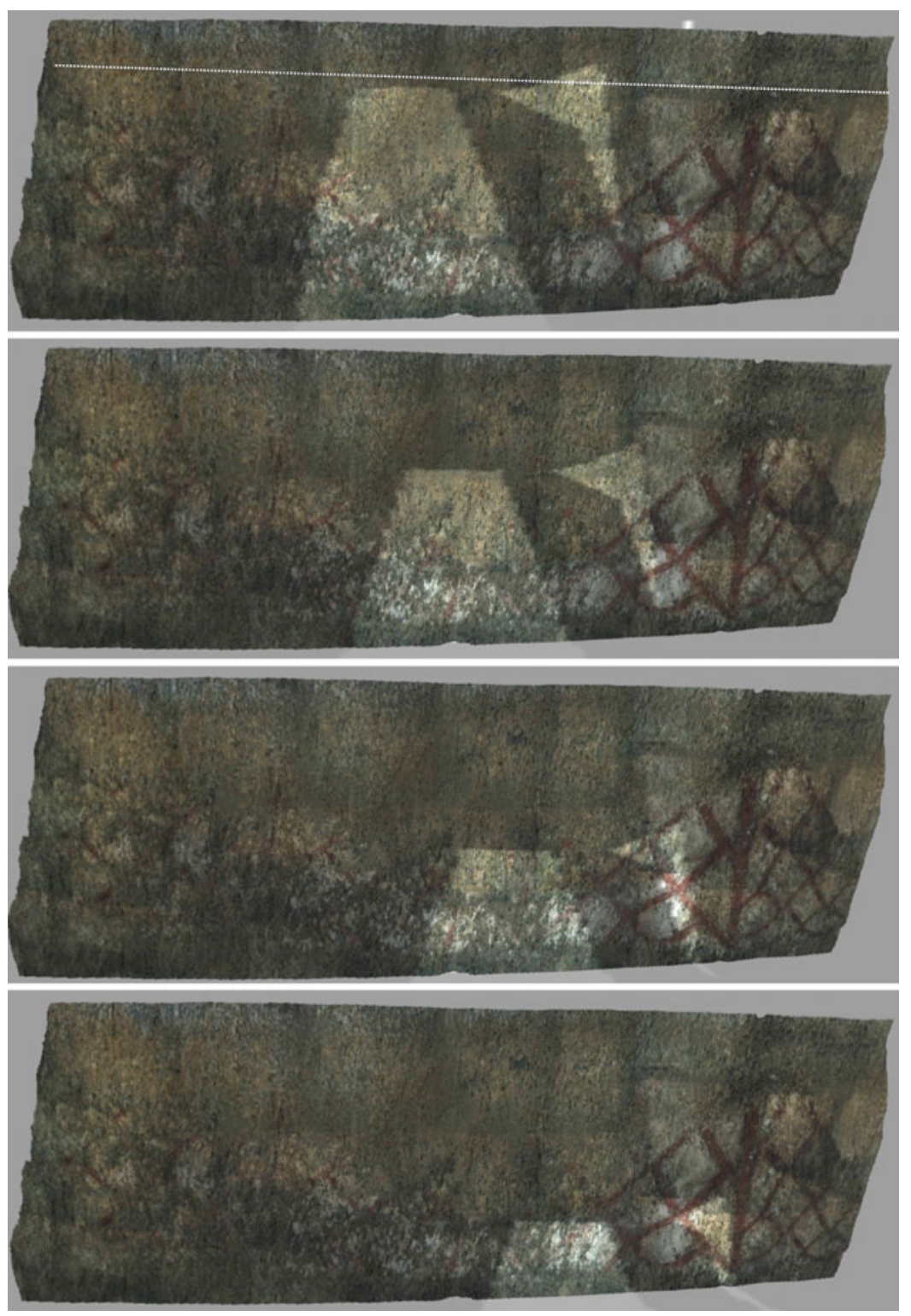

Figure 7. Reconstruction of the illuminated part of the back stone if the closing stone were removed after the simulations described in the text. As the sun climbs up in the sky and moves towards the south, the illuminated area becomes progressively smaller, and shifts towards the northern edge of the stone. The horizontal dotted line indicates the level of the upper part of the red paintings.

space. This direction, when taken together with the light coming from celestial bodies and their regular motions, may tell us something about the temporality (understood as the social comprehension of the flow of time) for the people who built the space (Gell 1992, 314-28; Knapp \& Ashmore 1999, 3). Arguably, this time could be highlighted by the use of light and shadow (MacKie 1997).

One of the main concerns when discussing illumination events inside a megalithic chamber is the intentionality of the builders in incorporating such phenomena in the original design, commonly accepted for monuments such as Newgrange (Patrick 1974; Ray 1989), but more difficult to ascertain for other kind of monuments (McCluskey 2015. Considering this, what arguments can we put forward for exploring further such intentionality in those monuments?

As a note of caution, one could first argue that the events such as those exposed here could be nonintentional. We could reject this null hypothesis if there were other cases with similar characteristics. 
In the case of Galicia, we have shown that the orientation towards WSSR is the most common one (González-García et al. 2017). Among them, there are other passage graves where a decorative programme similar to that of Dombate appears in a WSSR-oriented chamber. This is the case of Forno dos Mouros, mentioned above (Aboal \& Porto 2012), although the preservation of the whole monument prevents making a full parallel with the case study presented here.

Internal disposition of the monument may indicate intentionality in two ways. First, and although it could be artificially lit, it should be noted that most of the time the megalithic chamber would be in darkness, relating darkness with the realm of the dead; the direction of natural light towards the inner sanctum that occurs only at specific times of the year in several European monuments (Burl 1983, 29-30; Burrow 2010; Hensey 2017; MacKie 1997; Patrick 1974; Prendergast 2014, 1273; Ray 1989; Saletta 2011) may then suggest an intentionality aimed at signalling specific moments deemed important for the life cycle of the community. Secondly, the interaction of plays of light and shadow with specific architectural -(e.g. orthostats, internal divisions) or material (e.g. archaeological deposits, human bodies) elements has been much less studied and can also be seen as reflecting such intentionality.

Both aspects, as has been stated earlier, can be seen as part of the logic of integration of the architectures into the surrounding landscape and of the incorporation of the surrounding landscape into the architectures (Anschuetz et al. 2001; Ashmore 2008; Knapp \& Ashmore 1999).

The monument of Dombate appears as a relevant case for this discussion. Not only does the light enter the monument at a specific time of the year (WSSR), but the sunlight interacts in a very particular way with one of the most relevant and originally conspicuous elements within the passage grave: its 'decorative'-symbolic-programme. We have seen how the paintings seem to be organized into two vertical levels, separated by a horizontal red band. While those in the upper register have almost completely disappeared from the chamber, evidence from the corridor suggests that they consisted of zigzags made in black; those in the lower level were more complex and consisted of red bands delimiting varied irregular spaces. In particular, due to the overall orientation of the megalithic monument, the pattern of red and white geometrical paintings on the back stone appears to be illuminated only during a relatively short period before and after the winter solstice. Besides, this criss-cross painted pattern appears on this stone (and for that matter in the whole chamber and corridor) only at and below the level that would be directly illuminated by sunlight at winter solstice. Due to the aforementioned preservation conditions, there is debate about the actual presence of the paintings above the red band in the chamber. There are hints of black paintings above the red and white ones at certain areas in the corridor and it has been proposed that such pattern was general for the whole monument (Carrera Ramírez 2011, 240).

Indeed, one must consider the possibility that the illumination event can be purely coincidental. The fact that the painted pattern appears in the whole inner structure of the megalith could undermine the intentionality of the illumination event. Indeed, this could be the case, and we are not arguing here that the illumination event is the cause for the paintings. We would like to make clear that our argument is different: the separation in two levels could be caused by how the light and shadow areas appear at the moment of winter solstice on the back stone, the largest and arguably the most important in the monument, as it is the first one to be placed on site. It should also be remembered that the engravings appear only in the chamber and only at the levels that never get illuminated by direct natural light.

If there were originally no paintings above the red band, the illumination event could be read in terms of a duality between the decorated/undecorated areas of the back stone; if such paintings existed, the duality could be read in terms of a duality between the illuminated lower level (dominated by red and white paintings) and the upper level (dominated by black patterns, and the area where carvings have been recognized) that would remain in shadows of natural light. In both instances the illumination event would be relevant and meaningful.

Besides, this could also be another way to monumentalize the space for the dead. Indeed, such monumentalization is achieved by the use of massive stones and the construction of the mound, but the use of light incorporates a larger scheme, that of cyclical time and return into the durable stones and soil.

This begs the question as to whether this particular moment, WSSR, is important for any particular cultural reason. Orientations have been considered as ritual directions, related to ritual events or significant landscape features (Anschuetz et al. 2001; Rogelio-Candelera et al. 2018). In other words, the location of the megalithic monument could have been chosen so that the rising of the sun (for example) coincided with a particularly interesting point on the 


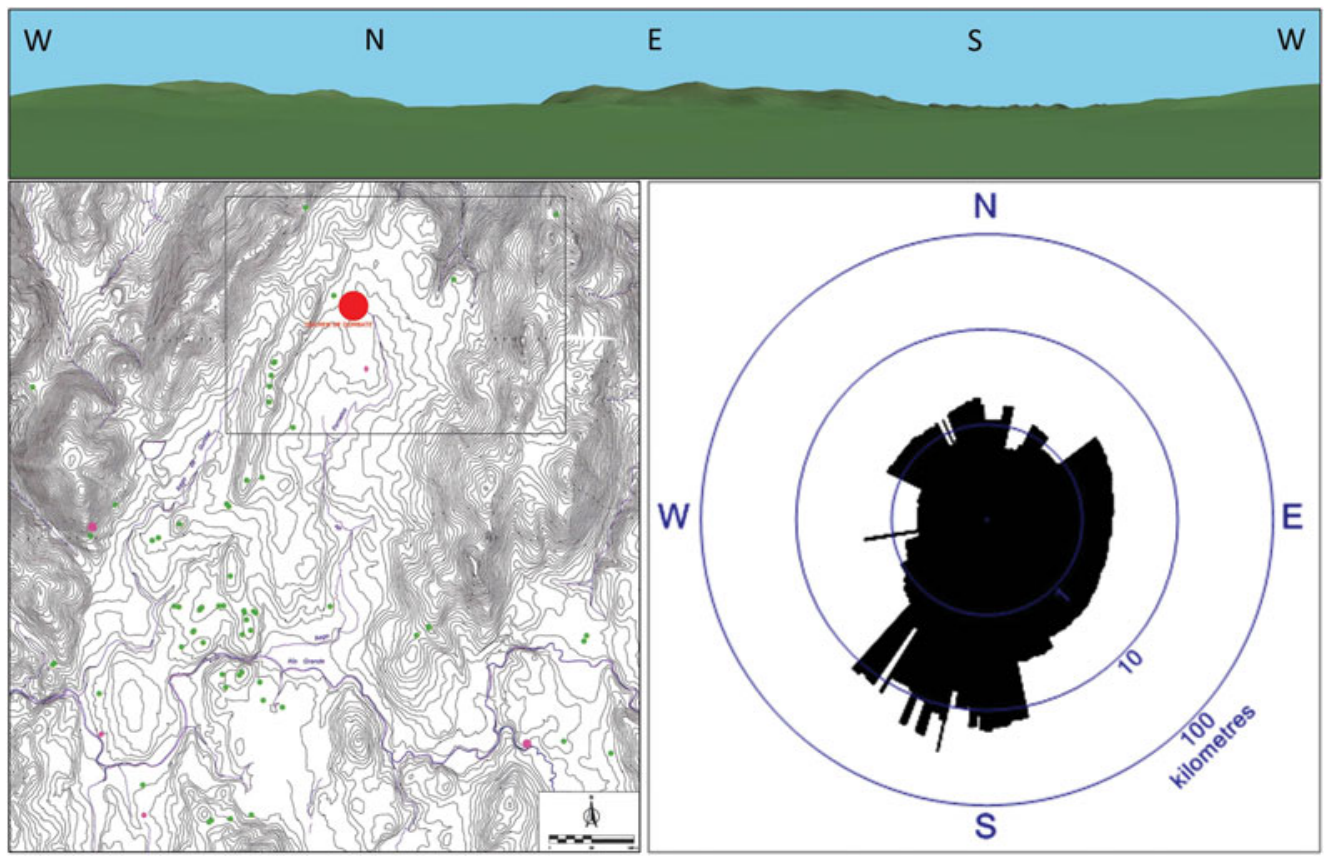

Figure 8. (Top) Reconstruction of the horizon seen from Dombate, done with a Digital Terrain Model and the software Horizon; (left) Topographic map with the location of Dombate marked as a dot; (right) Distance to the furthest horizon calculated with the software horizon. Horizons are closer towards north and west, while they are further away to the south and east.

horizon (MacKie 1997). Thus, if we consider that the illumination event is intentional, this could be considered as another element of the overall integration of the monument's architectonic elements and its surrounding landscape (Bradley 1989).

We argue that the illumination event is not the only feature indicating such integration. As mentioned above, the layer of stones covering the mound (coraza) is wider in the eastern part of the tumulus, on both sides of the dromos and corridor. This coincides with the area where the anthropomorphic idols were located. It is this part that would be first illuminated at sunrise, and it is this part that would be, at least at later times, connected with the domestic domain, as is suggested by the presence and location of ditch 1 . Indeed, this ditch is posterior to the construction of the monument, but the monument was still there and possibly was still valued when the ditch was built, as it respects the presence of the mound.

Most megalithic monuments in the area, passage graves with mounds and stone circles, have a variety of arrangements based on a circular shape (Gianotti et al. 2011). In generalizing this idea, some scholars have proposed that during the Neolithic there was a particular pattern for the organization of space. This was based on a circular configuration and a dual organization by halves (Criado-Boado \& Villoch-Vázquez 1998; Criado Boado et al. 2006; Gianotti et al. 2011). According to this scheme, megalithic funerary monuments in Galicia (although this might be extended to other areas of Iberia, such as Menga: see González-García 2018; see Higginbottom \& Clay 2016 for a similar approach to the British Isles) were placed in the landscape with one half of the area visible from them displaying a wide-open view, normally associated with the areas where the settlements were located. The other half offers closer horizons in general, and is more related to the wild part of the landscape.

Despite its position at the central part of a rather narrow plateau before the fall to the coast, the horizons found to the east and south of Dombate are rather different than those to the west and north (see Figure 8). The eastern and southern horizons seem to be further away, giving the impression that the view is wide open towards this side, although the farthest view is towards south. In contrast it is closer in distance towards the west and north. This may be signalling a distinction between the area for the living (east, or rather southeast) and that for the dead (west). It is worth remembering that the circular ditch 1 , of a later age, possibly associated with a living enclosure, was located at the southeastern edge of 
Dombate. Finally, it is worth noting that beyond the top of the ridges defining the north and west horizons one could see the Atlantic Ocean. In this sense Dombate would act as a nexus between the two areas.

The fact that the layer of stones covering the mound is wider in the eastern part, which is illuminated at sunrise, that such an area is commonly the one facing the further landscape, and that such area was later linked with the domestic domain, may indicate a concept of integrating light into the realm of the dead, particularly at selected moments of the solar cycle, perhaps as an image of a cyclical return to life (Bradley 1989) or as a time for the dead or the ancestors (Goodison 2001), with both explanations being compatible.

\section{Conclusions}

The dolmen of Dombate displays an unusual physical manifestation of sunlight, which particularly interacts with the decorated back stone. The light and shadow phenomenon occurs at sunrise during the period of winter solstice in a way that may have dictated how the overall decorative programme was incorporated into the passage grave. It appears that a vertical separation of the decorative elements could be connected with this phenomenon. Such differentiation could have had important cultural and ritual significance and encoded/embedded meaning for the tomb builders. We argue that such meaning had to do with how light and shadow may have been related with the living and the dead and perhaps with the correct time to perform some kind of ritual.

\section{Notes}

1. All dates in this paper have been calibrated at $2 \sigma$ using the IntCal 13 curve in OxCal (https://c14.arch.ox.ac. uk/oxcal.html).

2. Available at http://centrodedescargas.cnig.es/

3. http://stellarium.org/ version 0.16 .2 was used to produce the simulation and the video.

\section{Acknowledgements}

We would like to thank the Diputación de A Coruña for allowing us to enter the chamber of Dombate at several times during this investigation. We would also like to thank F. Criado for insightful discussions and comments on this manuscript, Georg Zotti for helping us during the implementation of the 3D model into the Stellarium software and A. Rodríguez Paz (Incipit, CSIC) for his contribution to Figure 2. ACGG is a Ramón y Cajal Fellow of the Spanish MINECO. ELR holds a Junior Chair in Neolithic societies (project: The memory of place: meaning, evolution and re- signification of space in the Neolithic of Western Europe) at the LabEx Sciences Archéologiques de Bordeaux (LaScArBx) in France.

\section{Supplementary material}

Video. 3D model of the dolmen of Dombate included in a DTM of the area and with the sky reproduced by Stellarium software for winter solstice sunrise at the moment of use of the dolmen (estimated for computation purposes to be around $3000 \mathrm{BC}$ ). The model includes the paintings of the back stone and the simulation shows that the illuminated part never reaches further up than the criss-cross pattern, perhaps indicating the intentionality of the orientation.

The supplementary material for this article can be found at https://doi.org/10.1017/S0959774318000562

A. César González-García Institute of Heritage Sciences, Incipit - CSIC Avda. de Vigo s/n 38200 Santiago de Compostela Spain

Email: a.cesar.gonzalez-garcia@incipit.csic.es

Benito Vilas-Estévez University of Vigo, Árbore arqueoloxía

Pabellón 1, 1a planta

Campus As Lagoas s/n 32004 Ourense Spain

Email:vieito4@hotmail.com

Elías López-Romero LabEx Sciences Archéologiques de Bordeaux (LaScArBx) Université de Bordeaux

8 Esplanade des Antilles 33607 Pessac cedex France Email: elias.lopez-romero@u-bordeaux-montaigne.fr

Patricia Mañana-Borrazás Institute of Heritage Sciences, Incipit - CSIC Avda. de Vigo s/n 15705 Santiago de Compostela Spain Email: patricia.manana-borrazas@incipit.csic.es

\section{References}

Aboal, R. \& Y. Porto (eds.), 2012. Intervencións de conservación e recuperación no xacemento de Forno dos Mouros (Toques, A Coruña). (Cadernos de Arqueoloxía 
e Patrimonio (CAPA) 31.) Santiago de Compostela: Incipit/CSIC.

Alonso Mathías, F. \& J.M. Bello Diéguez, 1995. Aportaciones del monumento de Dombate al megalitismo noroccidental; dataciones de Carbono $14 \mathrm{y}$ su contexto arqueológico. Trabalhos de Antropologia e Etnologia 35(1), 153-81.

Alonso Mathías, F. \& J.M. Bello Diéguez, 1997. Cronología y periodización del fenómeno megalítico en Galicia a la luz de las dataciones por carbono 14, in O Neolítico atlántico e as orixes do megalitismo, ed. A. Rodríguez Casal. Santiago de Compostela: Universidade de Santiago de Compostela, 507-20.

Anschuetz, K.F., R.H. Wilshusen \& C.L. Scheick, 2001. An archaeology of landscapes: perspectives and directions. Journal of Archaeological Research 9, 157-211.

Ashmore, W., 2008. Visions of the cosmos: ceremonial landscapes and civic plans, in Handbook of Landscape Archaeology eds. B. David \& J. Thomas. Walnut Creek (CA): Left Coast Press, 199-209.

Bayliss, A., C. Bronk Ramsey, J. van der Plicht \& A. Whittle, 2007. Bradshaw and Bayes: towards a timetable for the Neolithic, in Histories of the Dead: Building chronologies for five southern British long barrows. Cambridge Archaeological Journal 17 (Supplement S1), 1-28.

Bello Diéguez, J.M., 1992/1993. El monumento de Dombate en el marco del megalitismo del noroeste peninsular: aspectos arquitectónicos. Portugalia n.s. 13-14, 139-48.

Belmonte, J.A. \& A.C. González-García, 2016. Astronomy, landscape and power in eastern Anatolia, in Astronomy and Power: How worlds are structured, ed. M. Rappenglueck, B. Rappenglueck, N. Campion \& F. Silva. (BAR International series 2794.) Oxford: British Archaeological Reports, 31-6.

Belmonte, J.A. \& M. Hoskin, 2002, Reflejos del Cosmos. Madrid: Equipo Sirius.

Bentley, R.A., L. Chikhi, \& T.D. Price, 2003. The Neolithic transition in Europe: comparing broad scale genetics and local scale isotopic evidence. Antiquity 77, 63-6.

Bonilla Rodríguez, A., M. César Vila \& R. Fábregas Valcarce, 2006. Nuevas perspectivas sobre el espacio doméstico en la Prehistoria reciente del NO: El poblado de Os Remedios (Moaña-Pontevedra). Zephyrus 59, 257-73.

Bosch, E., 2018. Çatalhöyük: a study of light and darkness a photo-essay, in The Oxford Handbook of Light in Archaeology, eds. C. Papadopoulos \& H. Moyes. Oxford: Oxford University Press. DOI: 10.1093/ oxfordhb/9780198788218.013.29

Bradley, R., 1989. Darkness and light in the design of megalithic tombs. Oxford Journal of Archaeology 8(3), 251-9.

Bradley, R. \& H. Williams (eds.), 1998. The Past in the Past. The reuse of ancient monuments. (World Archaeology 30 (1).) London: Routledge.

Breuil, H., 1933. Les peintures rupestres schématiques de la Péninsule Ibérique. Vol. I. Au Nord du Tage. Lagny: Imprimerie de Lagny.
Burl, A., 1983. Prehistoric Astronomy and Ritual. Princes Risborough: Shire Archaeology.

Burrow, S., 2010. Bryn Celli Ddu passage tomb, Anglesey: alignment, construction, date and ritual. Proceedings of the Prehistoric Society 76, 249-70.

Carrera Ramírez, F., 2011. El arte prehistórico y su conservación. Pinturas y grabados en Dombate, in El dolmen de Dombate: arqueología, arquitectura y conservación, eds. F. Cebrian del Moral \& J. Yáñez Rodríguez. A Coruña: Diputación de A Coruña, 229-66.

Carrera Ramírez, F. \& J.M. Bello Diéguez, 1997. Las pinturas del monumento megalitico de Dombate, in $O$ Neolitico atlántico $e$ as orixes do megalitismo, ed. A. Rodríguez Casal. Santiago de Compostela: Universidade de Santiago de Compostela, 819-28.

Cebrián del Moral, F. \& J. Yáñez Rodríguez, 2011. Otros estudios técnicos, in El dolmen de Dombate: arqueología, arquitectura y conservación, eds. F. Cebrian del Moral \& J. Yáñez Rodríguez. A Coruña: Diputación de A Coruña, 267-310.

Criado Boado, F., 2012. Arqueológicas: La razón perdida. Barcelona: Bellaterra.

Criado Boado, F., 2015. Archaeologies of space: an inquiry into modes of existence of Xscapes, in Paradigm Found: Archaeological theory - present, past and future. Essays in honour of Evžen Neustupný, ed. K. Kristiansen, L. Šmejda \& J. Turek. Oxford/ Philadelphia: Oxbow Books, 61-83.

Criado Boado, F., C. Gianotti García \& P. Mañana-Borrazás, 2006. Before the barrows: forms of monumentality and forms of complexity in Iberia and Uruguay, in Archaeology of Burial Mounds, ed. L. Smejda. Pilsen: University of West Bohemia, 38-52.

Criado Boado, F., C. Gianotti García \& V. Villoch Vázquez, 2000. Los túmulos como asentamientos, in III Congreso de Arqueología Peninsular (Vila Real, September 1999) vol. 3, ed. V.O. Jorge. Porto: ADECAP, 289-302.

Criado-Boado, F. \& V. Villoch-Vázquez, 1998, La monumentalización del paisaje: percepción y sentido original en el megalitismo de la Sierra de Barbanza (Galicia). Trabajos de Prehistoria 55(1), 63-80.

Domínguez-Bella, S. \& M.J. Bóveda Fernández, 2011. Variscita y ámbar en el Neolítico gallego. Análisis arqueométrico del collar del túmulo 1 de Chousa Nova, Silleda (Pontevedra, España). Trabajos de Prehistoria 68(2), 369-80.

Fábregas Valcárce, R., 1993. Las representaciones de bulto redondo en el megalitismo del Noroeste. Trabajos de Prehistoria 50, 87-101.

García Quintela, M.V. \& A.C. González-García, 2009. Arqueoastronomía, antropología y paisaje. Complutum 20(2), 39-54.

Gell, A., 1992. The Anthropology of Time. London: Berg.

Gianotti, C., P. Mañana-Borrazás, F. Criado-Boado \& E. López-Romero, 2011. Deconstructing Neolithic monumental space: the Montenegro Enclosure in 
Galicia (northwest Iberia). Cambridge Archaeological Journal 21(3), 391-406.

Gkiasta, M., T. Russell, S. Shennan \& J. Steele, 2003. Neolithic transition in Europe: the radiocarbon record revisited. Antiquity 77, 45-62.

González-García, A.C., 2018. Light and shadow effects in megalithic monuments in the Iberian Peninsula, in The Oxford Handbook of Light in Archaeology, eds. C. Papadopoulos \& H. Moyes. Oxford: Oxford University Press. DOI: 10.1093/oxfordhb/ 9780198788218.013.6

González-García, A.C. \& J.A. Belmonte, 2010. Statistical analysis of megalithic tombs orientations in the Iberian Peninsula and neighbouring regions. Journal for the History of Astronomy 41, 225-38.

González-García, A.C., F. Criado-Boado \& B. Vilas, 2017. Megalithic skyscapes in Galicia, in The Marriage of Astronomy and Culture, eds. L. Henty, B. Brady, D. Ginzburg, F. Prendergast \& F. Silva. (Special issue.). Culture and Cosmos 21(1\&2), 87-103.

Goodison, L., 2001. From Tholos tomb to throne room: perceptions of the Sun in Minoan ritual, in Potnia: Deities and religion in the Aegean Bronze Age. Proccedings of the 8th International Aegean Conference, eds. R. Laffineur \& R. Hägg. (Aegaeum 22.) Liège: Université de Liège, 77-88.

Hedges, J.W., 1984. Tomb of the Eagles: Death and life in the Stone Age tribe. New York (NY): New Amsterdam.

Hensey, R., 2017. Rediscovering the winter solstice alignment at Newgrange, Ireland, in The Oxford Handbook of Light in Archaeology, eds. C. Papadopoulos \& H. Moyes. Oxford: Oxford University Press. DOI: 10.1093/oxfordhb/ 9780198788218.013.5

Higginbottom, G. \& R. Clay, 2016. Origins of standing stone astronomy in Britain: new quantitative techniques for the study of archaeoastronomy. Journal of Archaeological Science: Reports 9, 249-58.

Hoskin, M., 2001. Tombs, Temples and their Orientations: A new perspective in Mediterranean prehistory. Bognor Regis: Ocarina Books.

Iwaniszewski, S., 1989. Exploring some anthropological theoretical foundations for archaeoastronomy, in World Archaeoastronomy, ed. A.F. Aveni. Cambridge: Cambridge University Press, 27-37.

Jorge, V.O., 1987. Campo arqueológico da Serra da Aboboreira. Arqueologia do concelho de Baião. Resultados de 10 anos de trabalho. Arqueologia 17, 5-27.

Knapp, A.B. \& W. Ashmore, 1999. Archaeological landscapes: constructed, conceptualized, ideational, in Archaeologies of Landscape: Contemporary perspectives, eds. W. Ashmore \& A.B. Knapp. Malden (MA): Blackwell. 1-30.

Laporte, L., R. Joussaume \& C. Scarre, 2002. The perception of space and geometry, in Monuments and Landscape in Atlantic Europe: Perception and society during the Neolithic and Early Bronze Age, ed. C. Scarre. London/New York: Routledge, 73-83.
Leisner, G., 1938. Verbreitung und Typologie der Galizisch-Nordportugiesischen Megalithgräber. Marburg: Philipps-Universität zu Marburg.

Lestón Gómez, M., 2011. Las excavaciones arqueológicas, in El dolmen de Dombate: arqueología, arquitectura y conservación, eds. F. Cebrián del Moral \& J. Yáñez Rodríguez. A Coruña: Diputación de A Coruña, 139-266.

López-Romero, E., 2013. La investigación de las arquitecturas y paisajes monumentales del Neolítico en el noroeste peninsular: una aproximación bibliométrica. Complutum 24(1), 69-89.

López-Romero, E., A. Güimil-Fariña, P. Mañana-Borrazás, C. Otero Vilariño, P. Prieto Martínez, J.M. Rey García \& X.I. Vilaseco Vázquez, 2015. Ocupación humana y monumentalidad durante la Prehistoria Reciente en el islote de Guidoiro Areoso (Ría de Arousa, Pontevedra): investigaciones en el marco de las dinámicas litorales atlánticas actuales. Trabajos de Prehistoria 72(2), 353-71.

Lozano, J.A., G. Ruiz-Puertas, M. Hódar-Correa, F. Pérez-Varela \& A. Morgado, 2014. Prehistoric engineering and astronomy of the great Menga Dolmen (Málaga, Spain). A geometric and geoarchaeological analysis. Journal of Archaeological Science 41, 759-71.

MacKie, E.W., 1997. Maeshowe and the winter solstice: ceremonial aspects of the Orkney Grooved Ware culture. Antiquity 71, 338-59.

Magli, G., 2016. Sirius and the project of the Megalithic enclosures at Gobekli Tepe. Nexus Network Journal $18,337-46$.

Mañana-Borrazás, P., 2005. Túmulo 5 de Forno dos Mouros (Ortigueira, A Coruña). Primeiros resultados. Cuadernos de Estudios Gallegos 52(118), 39-79.

McCluskey, S.C., 2015. Analyzing light-and-shadow interactions, in Handbook of Archaeoastronomy and Ethnoastronomy, ed. C.L.N. Ruggles. New York (NY): Springer, 427-44.

Méndez Fernández, F., 2007. Excavación arqueológica en el túmulo de As Gándaras - Camposa (San Xoán de Vilanova, Miño, A Coruña). Technical report. Servizo de Arqueoloxía, Dirección Xeral de Patrimonio Cultural, Xunta de Galicia.

Murguía, M., 1865. Historia de Galicia. Tomo Primero. Lugo: Imprenta de Soto Freire.

Patrick, J., 1974. Midwinter sunrise at Newgrange. Nature 249, 517-19.

Pettitt, P., S. Leluschko \& T. Sakamoto, 2017. Light, human evolution, and the Palaeolithic, in The Oxford Handbook of Light in Archaeology, eds. C. Papadopoulos \& H. Moyes. Oxford: Oxford University Press. DOI: 10.1093/oxfordhb/9780198788218.013.1

Prendergast, F., 2014. Boyne Valley tombs, in Handbook of Archaeoastronomy and Ethnoastronomy, ed. C.L. N. Ruggles. New York (NY): Springer, 1263-76.

Prieto Martínez, M.P., 2010. La cerámica de O Regueiriño (Moaña, Pontevedra): nueva luz sobre el Neolítico en Galicia. Gallaecia 29, 63-82. 
Prieto Martínez, M.P., P. Mañana Borrazás, M. Costa Casais, F. Criado Boado, J.A. López Sáez, Y. Carrión Marco \& A. Martínez Cortizas, 2012. Galicia, in El neolítico en la Península Ibérica y su contexto europeo, eds M.A. Rojo Guerra, R. Garrido Pena \& I. García-Martínez de Lagrán. Madrid: Cátedra, 213-54.

Ray, T.P., 1989. The winter solstice phenomenon at Newgrange, Ireland: accident or design? Nature 337, 343-5.

Renfrew, C. 1994. Towards a cognitive archaeology, in The Ancient Mind: Elements of a cognitive archaeology, ed. C. Renfrew \& E. Zubrow. Cambridge: Cambridge University Press, 3-12.

Robb, J. 2013. Material culture, landscapes of action, and emergent causation: a new model for the origins of the European Neolithic. Current Anthropology 54(6), 657-83.

Rogerio-Candelera, M.A., P. Bueno Ramírez, R. de Balbín-Behrmann, et al., 2018. Landmark of the past in the Antequera megalithic landscape: a multidisciplinary approach to the Matacabras rock art shelter. Journal of Archaeological Science 95, 76-93.

Ruggles, C., 1999. Astronomy in Prehistoric Britain and Ireland. New Haven (CT): Yale University Press.

Ruggles, C.L. \& N.J. Saunders, 1993. The study of cultural astronomy, in Astronomies and Cultures, eds. C. L. Ruggles \& N.J. Saunders. Niwot (CO): University Press of Colorado, 1-31.

Saletta, M., 2011. The archaeoastronomy of the megalithic monuments of Arles-Fontvieille, in Archaeoastronomy and Ethnoastronomy: Building bridges between cultures, ed. C.L.N. Ruggles. Cambridge: Cambridge University Press, 364-73.

Schaeffer, B.E., 1993. Astronomy and the limits of vision. Vistas in Astronomy 36, 311-61.

Schmidt, K., 2006. Sie bauten die ersten Tempel. Das rätselhafte Heiligtum der Steinzeitjäger. Die archäologische Entdeckung am Göbekli Tepe. Munich: C.H. Beck.

Shennan, S., 2013. Demographic continuities and discontinuities in Neolithic Europe: evidence, methods and implications. Journal of Archaeological Method and Theory 20, 300-311.

Sherratt, A., 1990. The genesis of megaliths: monumentality, ethnicity and social complexity in Neolithic north-west Europe. World Archaeology 22(2), 14767.

Silva, F., 2014. A tomb with a view: new methods for bridging the gap between land and sky in megalithic archaeology. Advances in Archaeological Practice 2(1), 24-37.

Silva, F. \& L. Henty, 2015. Editorial. Journal of Skyscape Archaeology 1(1), 1-7.

Sprajc, I., 2018. Astronomy, architecture, and landscape in Prehispanic Mesoamerica. Journal of Archaeological Research 26, 197-251.

Steelman, K.L., F. Carrera Ramírez, R. Fábregas Valcárce, T. Guilderson \& M.W. Rowe, 2005. Direct radiocarbon dating of megalithic paints from north-west Iberia. Antiquity 79, 379-89.
Suárez Otero, J. 1997. Del yacimiento de A Cunchosa al neolítico en Galicia. Primera aproximación al contexto cultural de la aparición del megalitismo en Galicia, in O Neolítico atlántico e as orixes do megalitismo, ed. A. Rodríguez Casal. Santiago de Compostela: Universidade de Santiago de Compostela, 485-506.

Thomas, J., 2012. Los monumentos megalíticos de Europa, in El Neolítico en la Península Ibérica y su contexto europeo, eds. M.A. Rojo Guerra, R. Garrido Peña \& I. García Martínez de Lagrán. Madrid: Cátedra, 55-69.

Vicent García, J.M., 1991. El Neolítico, transformaciones sociales y económicas. Boletín de Antropología Americana 24, 3-62.

Zilhão, J., 2000. From the Mesolithic to the Neolithic in the Iberian Peninsula. in Europe's First Farmers, ed. T. D. Price. Cambridge: Cambridge University Press, 144-82.

Zotti, G., 2016. Open-source virtual archaeoastronomy. Mediterranean Archaeology and Archaemetry 16(4), 17-24.

Zvelebil, M. 1990. Mesolithic prelude and Neolithic revolution, in Hunters in Transition, ed. M. Zvelebil. Cambridge: Cambridge University Press, 5-15.

\section{Author biographies}

Antonio César González-García is a Ramón y Cajal Fellow at the Institute of Heritage Sciences - Incipit, of the Spanish National Research Council (CSIC, Santiago de Compostela Spain). He has a PhD in Astronomy from the RijkUniversiteit Groningen and his research focuses on Cultural Astronomy and the social impact of the sky in ancient societies. He is author of 'Light and Shadow effects in megalithic monuments in the Iberian Peninsula' in the Oxford Handbook of Light in Archaeology (Oxford University Press, 2017). Other relevant publications appear in Culture $\mathcal{E}$ Cosmos (2017) and the Journal for the History of Astronomy (2011; 2012).

Elías López-Romero holds a Junior Chair in Neolithic Societies at the LaScArBx (Bordeaux, France). His research focuses on the monumental landscapes of the European Atlantic façade and on coastal archaeology. He is co-editor of and author in Public Archaeology and Climate Change (Oxbow, 2017). Other relevant publications appear in the Proceedings of the Geologists' Association (2015), Antiquity (2014), Journal of Island and Coastal Archaeology (2012), Cambridge Archaeological Journal (2011) and Oxford Journal of Archaeology (2008).

Patricia Mañana Borrazás is an archaeologist at Incipit, specializing in megalithic monuments, archaeology of buildings, landscape archaeology and the Neolithic. She has experience as a technician of geometric and 3D documentation of Cultural Heritage, specializing in digital data acquisition and visualization with several devices (3D scanners, photogrammetry, classical topography and GIS) and Virtual Archaeology. Relevant references are 'Deconstructing Neolithic monumental 
space: the Montenegro enclosure in Galicia (Northwest Iberia)', Cambridge Archaeological Journal 21(3), 391-406.

Benito Vilas Estévez is an archaeologist, MSc in Cultural Astronomy at the University of Wales-Trinity Saint David and MSc in Archaeology at the University of Santiago and currently completing a degree in Geography at the University of Vigo. He has carried out studies on Megalithic Astronomy and other issues related to Cultural Astronomy. 